Arab Univ. J. Agric. Sci., Ain Shams Univ., Cairo, 14(1), 411-423, 2006

\title{
BIOLOGICAL CONTROL OF MELOIDOGYNE JAVANICA AND RHIZOCTONIA SOLANI ON SOYBEAN BY FORMULATION OF BACILLUS THURINGIENSIS AND TRICHODERMA HARZIANUM
}

[27]

\author{
Mahdy, M.E'; Rania Z. El-Shennawy ${ }^{2}$ and E.Z. Khalifa ${ }^{1}$
}

\begin{abstract}
Preparation of either Bacillus thuringiensis or Trichoderma harzianum were used as seed coating or soil application for management of root-knot and root rot disease complex caused by the root-knot nematode, Meloidogyne javanica and the fungus Rhizoctonia solani on soybean plants. Number of galls, root galling, egg masses and disease severity were reduced sharply on plants treated with both biocontrol agents, either as seed or soil application compared with non-treated plants. Soil application with both biocontrol agents was the best method in reducing nematode and fungus disease severity. Plant growth parameters i.e. fresh shoot and root weight, dry weight and number of pods and bacterial nodules were markedly increased with all treatments of biocontrol agent either with seed or soil treatment compared to plants grown in infested soil with either pathogens alone or combined. Results show that plant survival was more affected when $R$. solani was alone or combined with $M$. javanica. Seed coating was considered the effective method in increasing survival plants. The biochemical analysis of treated plants with both biocontrol agents were affected compared to non-treated plants grown in pathogen infested soil. The biochemical parameters i.e. chlorophyll A and B, carotein, phenols and amino acids were enhanced in bioagent treated plants compared to non-treated plants.
\end{abstract}

Keywords: Biological control, Trichoderma harzianum, Bacillus thuringiensis, Formulation, Meloidogyne javanica, Rhizoctonia solani, Soybean

\section{INTRODUCTION}

Soybean (Glycine max L. Merr) is one of the most important legume crops because it is considered a chief source of protein. In Egypt, a great interest has been focused towards this crop. There are several constraints in the successful cultivation of many leguminous crops.

Root-knot nematodes, $M$. javanica and $M$. incognita were reported in peanut, broadbean, cowpea and many leguminous

1- Department of Agriculture Botany, Faculty of Agriculture, Ain Shams University, Shoubra El-Kheima, Cairo, Egypt

2- Plant Pathology Research Institute, Agricultural Research Center, Giza, Egypt 
crops cultivated in sandy soils of newly reclaimed areas in Egypt. A great attention has been given to the interaction between the root-knot nematodes, M. javanica and the soil-borne fungus, Rhizoctonia solani on different crops i.e cotton, pea, tomato, tobacco and soybean (Hillocks, 1985; Mousa \& Hague, 1988 and Mousa et al 1989). They concluded that the interaction between the root-knot nematdes and soil-borne pathogenic fungi increased the incidence and severiy of the major soil-borne diseases.

The use of nematicides and fungicides for controlling nematodes and soil-borne fungi, respectively is not currently appropriate for food and fruit production in several countries because of their high costs, extreme toxicities and enviornmental pollution. Biological pesticides have been developed since they are environmentally safe, highly desirabl alternative to chemicals and have therefore received considerable attention.

The hyperparasite fungus, Trichoderma harzianum Rifai, has been reported to be one of the most promising biocontrol agents against plant-parasitic nematodes (Parvatha Reddy et al 1996). The most widely used microbial pesticides worldwide are the bacterium, Bacillus thuringiensis, which produce a wide variety of toxins (Schnepf $\boldsymbol{e t} \boldsymbol{a l} \mathbf{1 9 9 8}$ ). It has been shown that some crystal proteins made by B. thuringiensis are toxic to a wide range of nematodes (Aroian et al 2002). During the last decade, intensive studies of the nematicidal effects of Bacillus thuringiensis have been carried out against phytoparasitic nematodes such as Globodera pallida, Heterodera cajani and M. incognita (Mozgovaya et al 2002).

This research aimed to use alternative safe control method against disease complex caused by root-knot nematodes, $M$. javanica and root-rot fungus, $R$. solani on soybean.

\section{MATERIAL AND METHODS}

\section{Pathogens and inoculum preparation}

Root-knot nematode, $M$. javanica inoculum was obtained from heavily infected black nightshade roots (Solanum nigrum L.). Stock culture of nematode were multiplied under greenhouse condition at $25^{\circ} \mathrm{C}$ on tomato plants (Lycopersicon esculentum cv. Castle Rock) grown in $30 \mathrm{~cm}$ diameter plastic pots filled with a soil-sand mixture $(1: 2, \mathrm{v} / \mathrm{v})$. Eggs of $M$. javanica were extracted from heavily galled tomato roots using sodium hypochlorite (NaOCL) method as described by Hussey and Barker (1973).

Rhizoctonia solani was isolated from soybean roots and maintained on potato dextrose agar (PDA). Fungus inoculum was prepared by culturing the isolate in potato dextrose broth medium for 15 days at $25^{\circ} \mathrm{C}$. Mycelium was collected on sterilized filter paper to remove excess nutrients. One hundered gram of mycelium was macerated in $1000 \mathrm{ml}$ distilled water and $10 \mathrm{ml}$ of this suspension containing 1 $\mathrm{g}$ fungus inoculum added to soil in each pot (Siddiqui and Mahmood, 1995).

\section{Source of bioagents}

Two biocontrol agents were used in this work: i.e. the bacterium Bacillus thuringiensis and the fungus Trichoderma harzianum. Both bioagents were obtained from the Agricultural Botany Department Collection, Faculty of Agriculture, Menofiya University, Shebin El-kom, Egypt. Culture of B. thuringiensis and T. harzi- 
anum were maintained on T3 medium (Travers $\boldsymbol{e t}$ al 1987) and Gliotoxin fermentation Medium Agar [GFMA] (Brian and Hemming, 1945) in petri dishes (6 $\mathrm{cm}$ in diam.).

\section{Formulation of bioagents}

The biomass of each bioagent was produced by inoculation of $500 \mathrm{ml}$ flasks containing $200 \mathrm{ml}$ of T3 broth medium with bacterial loop of $B$. thuringiensis and GFMB medium with equal disks of $T$. harzianum. Flasks were incubated on a rotary shaker at $250 \mathrm{rpm}$ at $28^{\circ} \mathrm{C}$ for 3 and 15 days, for $B$. thuringiensis and $T$. harzianum respectively.

The biomass of $B$. thuringiensis was collected by centrifugation at $5000 \mathrm{rpm}$ for 10 minutes and the supernatant was discarded. The resulting pellet was resuspended in $400 \mathrm{ml}$ of phosphate buffer $\mathrm{pH}$ 7.0 as a final volume and stored in refrigerator until use.

The biomass of T. harzianum was collected by filteration through sterilized filter papers (Whatman No.1), homogenized and stored in refrigerator until use. Mixture of $10 \mathrm{gm}$ of carboxylmethyl cellulose (CMC) and $1 \mathrm{~kg}$ of talc powder were used to prepare the talc powder formulation as described by Vidhyasekaran and Muthamilan (1995).

Both bacterial suspension $(400 \mathrm{ml})$ and fungus homogenized biomass (400 $\mathrm{ml}$ ) were added to the carrier (1 $\mathrm{kg}$ talc powder for each bioagent) and mixed well under sterilized conditions to form a pasta. The pasta was air dried in laminar flow hood for $24 \mathrm{hrs}$. The dried product was powdered using a blender, sieved and packed in polyethylene bags. One gram sub-samples of each biocontrol agent powder was taken to count the colony forming unites (cfu/g) of bacterial and fungal population by using dilution plate technique on T3 and GFMA media.

\section{Evaluation of bioagents}

An experiment was carried out under greenhouse conditions at Faculty of Agriculture, Menofiya University, Shebin Elkom, Egypt. Powder formulations of both bio-control agents were used either as seed or soil treatment.

Plastic pots $(25 \mathrm{~cm}$ diam.) containing autoclave-sterilized sand-soil mixture $(2: 1 \mathrm{v} / \mathrm{v})$ was prepared and infested by $R$. solani and/or $M$. javanica. Soil was infested with both bioagents at the same time with both pathogens at sowing time.

Eggs of $M$. javanica were extracted as mentioned previously and was inoculated by pipetting 1500 eggs under the soybean seeds.

\section{Seed Treatment}

Soybean seeds cv. Giza 21 were surface sterilized with $2.4 \%$ sodium hypochlorite solution for 2-3 min., rinsed in sterile distilled water and air dried overnight under laminar flow hood. Seeds were treated with the powder formulation at the rate of $1 \mathrm{~g} / 100 \mathrm{~g}$ seeds as slurry treatment according to Weller and Cook (1983). The slurry was prepared by mixing $10 \mathrm{~g}$ powder in $40 \mathrm{ml}$ of sterilized water.

\section{Soil Treatment}

Soil treatment was carried out by mixing the powder formulation of each bioagent throughly with sand-soil mixture at the rate of $1 \%$ of soil weight $(10 \mathrm{~g} / 1 \mathrm{~kg}$ soil). Five treated seeds with both bio- 
agents and non-treated were sown in each pot and each treatment was replicated three times.

Non-treated seeds and soil served as control and plants were arranged in a completely randomized block design in the greenhouse at approximately $25^{\circ} \mathrm{C}$. Plants were fertilized weekly with a nutrient solution. Pre- and post-emergence damping-off were recorded after 15 and 30 days of sowing respectively.

Eight weeks after nematode inoculation, plant growth parameters i.e shoot and root fresh weight, dry weight, number of pods and number of bacterial nodules as well as root galling in 0-5 scale according to Taylor and Sasser (1978), number of galls, egg masses and disease severity index were determined. Egg masses were stained prior to counting with $0.015 \%$ Phloxine B for 20 minutes as described by Daykin and Hussey (1985). Disease severity index was calculated according to Koberiger $\boldsymbol{e t}$ al (1998) where:

\section{$D I=[$ Sum of (disease class $x$ num- ber of plants in class) $x$ 100] $\div$ [(total plants) $x$ 4]}

Changes in chemical compostion in plants associated with $M$. javanica and/or $R$. solani as well as biocontrol agents treatment were determined for chlorophyll A and B, carotenoids (Wettestein, 1957), phenol (Snell and Snell, 1953) and total amino acids (Rosen, 1957).

\section{Statistical analysis}

Data were statistically analyzed by analysis of variance (ANOVA) using the software Statgraphics Version 3.1 for windows. Duncan's Multiple Test was used to test for significant differences among means at $\mathrm{P}<0.05$.

\section{RESULTS}

Data in Table (1) revealed that adding $B$. thuringiensis and/or $T$. harzianum, either as seed coating or soil application significantly reduced the nematode severity on soybean plants compared with nontreated. Soil treatment was better than seed coating in reducing nematode infection severity parameters where number of galls, root galling and number of egg masses per root system were lower than those produced due to seed coating treatment.

The reduction in number of galls was 92\% for $T$. harzianum against $M$. javanica alone and $M$. javanica plus $R$. solani. For $B$. thuringiensis, the rate of galls reduction was $83 \%$ against $M$. javanica alone and $89 \%$ against $M$. javanica plus $R$. solani. As for number of egg masses, the rate of reduction was 97 and $94 \%$ for $T$. harzianum either against $M$. javanica alone or $M$. javanica plus $R$. solani respectively. Treatments with $B$. thuringiensis showed $92 \%$ and $99 \%$ reduction respectively. In general, all treated plants with both biocontrol agents showed significant reduction in nematode parameters especially as soil treatment compared with non-treated plants.

Results in Table (1) showed also that the treated plants with both biocontrol agents decreased the disease severity index caused by $R$. solani alone or combined with $M$. javanica. The lowest disease severity $(60 \%)$ was observed with seeds treated with $T$. harzianum against $M$. javanica alone followed by the 
Table 1. Biological control of root-knot and root-rot disease complex caused by rootknot nematode, $M$. javanica and root-rot fungus, $R$. solani on soybean.

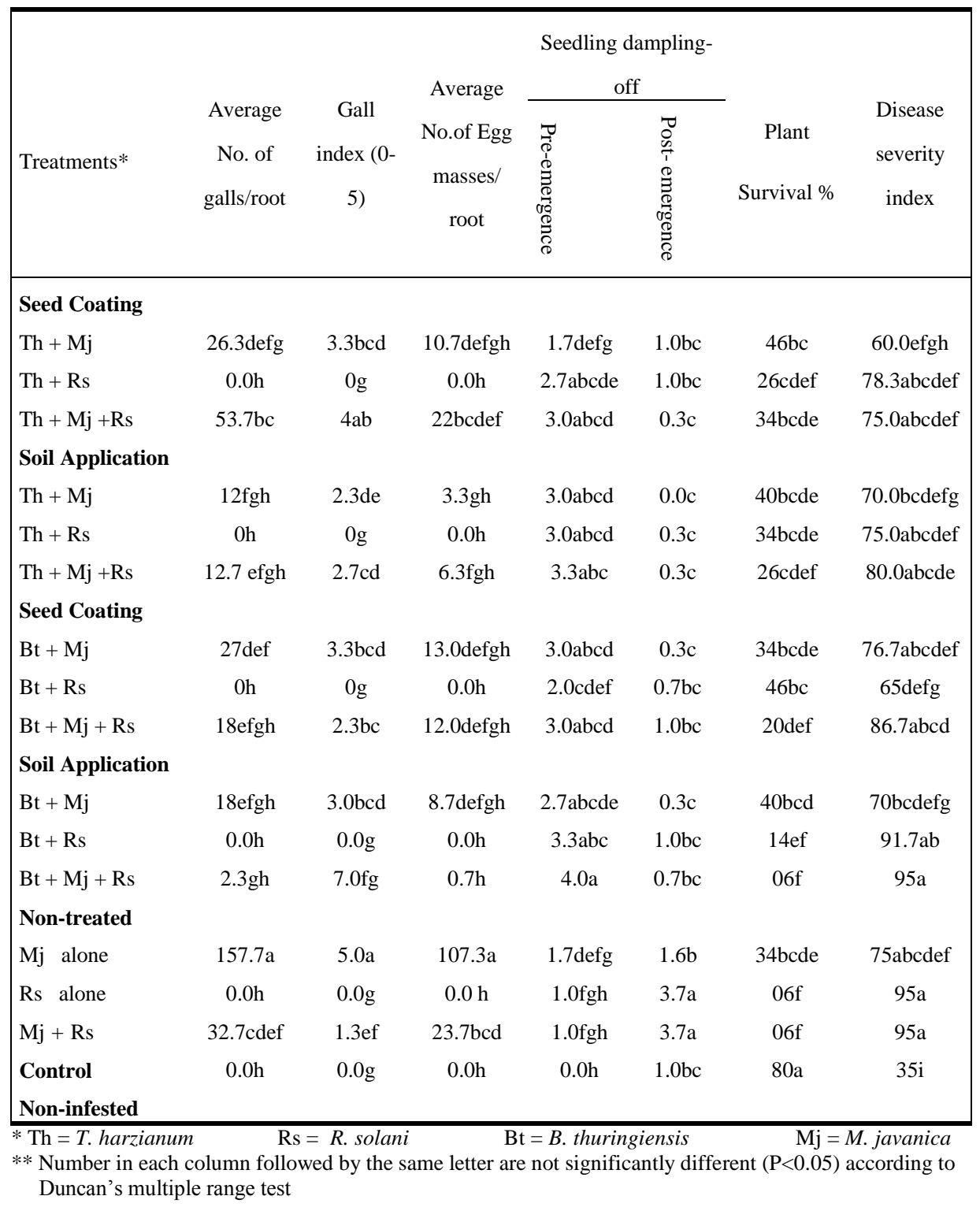


treatment with $B$. thuringiensis as seed coating against $R$. solani $(65 \%)$ compared with $95 \%$ on bioagents non-treated control.

Data presented in Table (1) show that the treatment with both biocontrol agents either as seed or soil treatments were enhanced slightly the percentage of survival plants compared with the bioagents nontreated plants. Results revealed that the highest percentage of survival plants were showed with plants treated with T. harzianum as seed coating.

Results in Table (1) showed that no significant differences in root-rot disease severity when $M$. javanica was combined with $R$. solani compared to plants grown in soil infested with R.solani alone.

Data presented in Table (2) revealed that adding both biocontrol agents, either as seed or soil application, enhanced markedly the plant growth parameters i.e shoot and root fresh weight, dry weight, number of pods and bacterial nodules compared with biocontrol agents nontreated plants grown in pathogen infested soil. The lowest values were recorded with plants grown in soil infested with $M$. javanica and $R$. solani alone and combined.

Results in Table (3) show remarkable changes in chemical composition of infected plants with both pathogens, $R$. solani and $M$. javanica alone or together compared with the infected plants treated with both biocontrol agents. Treatment with bioagents either as seed coating or soil treatment reduced the harmful effects of both pathogens on plant growth. Chlorophyll and carotein content in leaves of treated plants were slightly higher compared with non-treated control. Phenol content in treated plants with either bio- agent was higher than non-treated control plants and also non-infested control. Total amino acid content was also affected (Table 3).

Generally, it could be conducted that adding the biocontrol agents as seed or as soil application to infected plants positively improved the chemical composition i.e chlorophyll ( $\mathrm{a} \& \mathrm{~b}$ ), carotein, phenol and amino acids.

\section{DISCUSSION}

Results of the present study showed that adding both biocontrol agents, $B$. Thuringiensis or T. harzianum to infected soybean plants with $M$. javanica or $R$. solani enhanced plant growth parameters. These results may be due to the antagonistic effect of the biocontrol agents by inhibiting parasitic root pathogens, producing biologically active substances or by transformating unavailable mineral and organic compounds into forms available to plants (Broadbent et al 1977; Chet, 1987; Parvatha Reddy et al 1996 and Rao et al 1997).

Nematode severity i.e number of galls, root galling and number of egg masses was reduced significantly with both $B$. thuringiensis and T. harzianum either as seed or soil application, although soil application was better. These findings may be due to the bio-control activity during the infection process (Mahdy et al 2000 \& 2001) as Trichoderma (Papavizas, 1985 and Cherif \& Benhamou, 1990) and B. thuringiensis (Zuckerman et al 1995 and Wei et al 2001 \& 2003) produced various toxins and enzymes for Trichoderma and toxin crystals proteins for B. Thuringiensis that may be effective nematicides and play an important role to 
Table 2. Effect of treatment with biocontrol agents on certain growth characters of soybean plants grown in soil infested with $M$. javanica and $R$. solani

\begin{tabular}{|c|c|c|c|c|c|}
\hline Treatments* & $\begin{array}{c}\text { Fresh shoot } \\
\text { weight } \\
\text { (g)/plant }\end{array}$ & $\begin{array}{c}\text { Fresh } \\
\text { root weight } \\
(\mathrm{g}) / \text { plant }\end{array}$ & $\begin{array}{c}\text { Dry } \\
\text { weight } \\
\text { (g)/plant }\end{array}$ & $\begin{array}{c}\text { Average } \\
\text { No. of } \\
\text { Pods/plant }\end{array}$ & $\begin{array}{r}\text { Average No. } \\
\text { of bacterial } \\
\text { nodules/plan }\end{array}$ \\
\hline \multicolumn{6}{|l|}{ Seed Coating } \\
\hline $\mathrm{Th}+\mathrm{Mj}$ & 12.1bcde & 3.5abcde & $2.5 \mathrm{a}$ & 7.3bcdef & $18.0 \mathrm{a}$ \\
\hline $\mathrm{Th}+\mathrm{Rs}$ & 6.5efghij & 1.9efghij & $1.8 \mathrm{a}$ & 4.0efghij & $2.3 \mathrm{efg}$ \\
\hline $\mathrm{Th}+\mathrm{Mj}+\mathrm{Rs}$ & 10.1cdef & 3.5abcde & $2.1 \mathrm{a}$ & 3.3efghij & $9.3 \mathrm{bcd}$ \\
\hline \multicolumn{6}{|l|}{ Soil Application } \\
\hline $\mathrm{Th}+\mathrm{Mj}$ & $10.2 \mathrm{cdef}$ & $2.9 \mathrm{cdefg}$ & $1.2 \mathrm{a}$ & 4.7efghij & $2.7 \mathrm{efg}$ \\
\hline $\mathrm{Th}+\mathrm{Rs}$ & 7.4defghi & 2.2defghi & $2.8 \mathrm{a}$ & 6.0cdefgh & 7.3bcdef \\
\hline $\mathrm{Th}+\mathrm{Mj}+\mathrm{Rs}$ & 6.0efghij & 2.3defghi & $2.1 \mathrm{a}$ & 5.0efghij & $11.3 \mathrm{~b}$ \\
\hline \multicolumn{6}{|l|}{ Seed Coating } \\
\hline $\mathrm{Bt}+\mathrm{Mj}$ & 7.4defghi & $4.1 \mathrm{abc}$ & $2.6 \mathrm{a}$ & 7.0bcdefg & $10.3 \mathrm{bc}$ \\
\hline $\mathrm{Bt}+\mathrm{Rs}$ & $10.5 \mathrm{cdef}$ & 2.5defgh & $2.6 \mathrm{a}$ & 10.0abcd & $11.0 \mathrm{bc}$ \\
\hline $\mathrm{Bt}+\mathrm{Mj}+\mathrm{Rs}$ & 6.3efghij & 2.2defghi & $1.4 \mathrm{a}$ & 5.7defgh & $10.0 \mathrm{bcd}$ \\
\hline \multicolumn{6}{|l|}{ Soil Application } \\
\hline $\mathrm{Bt}+\mathrm{Mj}$ & 7.9defgh & 3.0cdefg & $1.9 \mathrm{a}$ & $10.7 \mathrm{abc}$ & $11.3 \mathrm{~b}$ \\
\hline $\mathrm{Bt}+\mathrm{Rs}$ & 4.4fghij & 1.5fghij & $2.5 \mathrm{a}$ & 2.7fghij & $3.7 \mathrm{defg}$ \\
\hline $\mathrm{Bt}+\mathrm{Mj}+\mathrm{Rs}$ & 4.5fghij & 0.4hij & $0.4 \mathrm{a}$ & $0.3 \mathrm{j}$ & $2.7 \mathrm{efg}$ \\
\hline \multicolumn{6}{|l|}{ Non-treated } \\
\hline $\mathrm{Mj}$ alone & 5.0fghij & 1.7efghij & $1.1 \mathrm{a}$ & 2.3ghij & $4.4 \mathrm{~d}$ \\
\hline Rs alone & $0.8 \mathrm{j}$ & $0.1 \mathrm{j}$ & $0.01 \mathrm{a}$ & $0.7 \mathrm{ij}$ & $2.9 \mathrm{~h}$ \\
\hline $\mathrm{Mj}+\mathrm{Rs}$ & $1.4 \mathrm{ij}$ & $0.3 \mathrm{ij}$ & $0.3 \mathrm{a}$ & $0.7 \mathrm{ij}$ & $1.8 \mathrm{i}$ \\
\hline $\begin{array}{l}\text { Control Non- } \\
\text { infested }\end{array}$ & $18.9 \mathrm{a}$ & $4.8 \mathrm{ab}$ & $2.7 \mathrm{a}$ & $13.0 \mathrm{a}$ & $2.2 \mathrm{hi}$ \\
\hline
\end{tabular}

$*$ Th $=$ T. harzianum $\quad \mathrm{Rs}=R$. solani $\quad \mathrm{Bt}=B$. thuringiensis $\quad \mathrm{Mj}=M$. javanica

** Number in each column followed by the same letter are not significantly different $(\mathrm{P}<0.05)$ according to Duncan's multiple range test 
Table 3. Effect of treatment with biocontrol agents on some chemical components changes in soybean plants grown in soil infested with $M$. javanica and $R$. solani.

\begin{tabular}{|c|c|c|c|c|}
\hline Treatments* & $\begin{array}{l}\text { Chlorophyll } \\
\qquad \begin{array}{c}a+b \\
\text { (mg/g dry } \\
\text { weight) }\end{array}\end{array}$ & $\begin{array}{l}\text { Carotenoids } \\
\text { (mg/g dry } \\
\text { weight) }\end{array}$ & $\begin{array}{l}\text { Phenol } \\
\text { (mg/g dry } \\
\text { weight) }\end{array}$ & $\begin{array}{c}\text { Amino Acid } \\
\text { (mg/g dry } \\
\text { weight) }\end{array}$ \\
\hline \multicolumn{5}{|l|}{ Seed Coating } \\
\hline $\mathrm{Th}+\mathrm{Mj}$ & $2.9 \mathrm{~h}$ & $1.6 \mathrm{c}$ & $3.2 \mathrm{~b}$ & $37.4 \mathrm{de}$ \\
\hline $\mathrm{Th}+\mathrm{Rs}$ & $4.4 \mathrm{~d}$ & $1.4 \mathrm{~d}$ & $2.3 \mathrm{~d}$ & $43.2 \mathrm{bc}$ \\
\hline $\mathrm{Th}+\mathrm{Mj}+\mathrm{Rs}$ & $3.3 \mathrm{fg}$ & $1.7 \mathrm{~b}$ & $2.5 \mathrm{~cd}$ & $20.9 \mathrm{I}$ \\
\hline \multicolumn{5}{|l|}{ Soil Application } \\
\hline $\mathrm{Th}+\mathrm{Mj}$ & $2.1 \mathrm{k}$ & $0.7 \mathrm{ij}$ & $3.2 \mathrm{~b}$ & $38.2 \mathrm{de}$ \\
\hline $\mathrm{Th}+\mathrm{Rs}$ & $4.6 \mathrm{c}$ & $1.2 \mathrm{efg}$ & $2.6 \mathrm{c}$ & $33.1 \mathrm{ef}$ \\
\hline $\mathrm{Th}+\mathrm{Mj}+\mathrm{Rs}$ & $4.4 \mathrm{~d}$ & $1.6 \mathrm{c}$ & $2.7 \mathrm{c}$ & $37.5 \mathrm{e}$ \\
\hline \multicolumn{5}{|l|}{ Seed Coating } \\
\hline $\mathrm{Bt}+\mathrm{Mj}$ & $3.2 \mathrm{~g}$ & $1.2 \mathrm{efg}$ & $3.6 \mathrm{a}$ & $44.3 b c$ \\
\hline $\mathrm{Bt}+\mathrm{Rs}$ & $6.0 \mathrm{a}$ & 0.8hi & $3.3 \mathrm{~b}$ & $39.0 \mathrm{~cd}$ \\
\hline $\mathrm{Bt}+\mathrm{Mj}+\mathrm{Rs}$ & $4.1 \mathrm{e}$ & $2.7 \mathrm{a}$ & $3.6 \mathrm{a}$ & $21.1 \mathrm{I}$ \\
\hline \multicolumn{5}{|l|}{ Soil Application } \\
\hline $\mathrm{Bt}+\mathrm{Mj}$ & $2.3 \mathrm{ijk}$ & $0.9 \mathrm{~h}$ & $2.7 \mathrm{c}$ & $40.5 \mathrm{~cd}$ \\
\hline $\mathrm{Bt}+\mathrm{Rs}$ & $5.2 \mathrm{~b}$ & $2.7 \mathrm{a}$ & $2.6 \mathrm{c}$ & $22.3 \mathrm{I}$ \\
\hline $\mathrm{Bt}+\mathrm{Mj}+\mathrm{Rs}$ & $3.4 \mathrm{f}$ & $1.7 \mathrm{~b}$ & $2.8 \mathrm{c}$ & $27.4 \mathrm{gh}$ \\
\hline \multicolumn{5}{|l|}{ Non-treated } \\
\hline $\mathrm{Mj}$ alone & $1.3 \mathrm{~m}$ & $0.4 \mathrm{kl}$ & $1.5 \mathrm{ef}$ & $62.4 \mathrm{a}$ \\
\hline Rs alone & $2.9 \mathrm{~h}$ & $1.1 \mathrm{fg}$ & $1.7 \mathrm{e}$ & $47.7 \mathrm{~b}$ \\
\hline $\mathrm{Mj}+\mathrm{Rs}$ & 1.81 & $0.7 \mathrm{ij}$ & $1.4 \mathrm{f}$ & $31.4 \mathrm{fg}$ \\
\hline $\begin{array}{l}\text { Control } \\
\text { Non-infested }\end{array}$ & $2.2 \mathrm{jk}$ & $0.9 \mathrm{~h}$ & $2.8 \mathrm{c}$ & $27.8 \mathrm{gh}$ \\
\hline
\end{tabular}

$* \mathrm{Th}=T$. harzianum $\quad \mathrm{Rs}=R$. solani $\quad \mathrm{Bt}=B$. thuringiensis $\quad \mathrm{Mj}=M$. javanica

** Number in each column followed by the same letter are not significantly different $(\mathrm{P}<0.05)$ according to Duncan's multiple range test 
retardation the egg hatching in soil and also affect the movement of hatched infective juveniles towards the host roots. Results showed that soil application was the best application method in reducing the nematode severity; this may be refered to the good distribution of the bioagents in soil, consequently the good colonization around roots which protect the roots towards by nematode juveniles.

Results showed also that adding both biocontrol agents, as seed coating treatment, led to decreased disease severity index caused by $R$. solani alone or when combined with $M$. javanica. These results may be due to the biological activity of the biocontrol agents against pathogens and where the bioagents were able to grow along with germinating seeds and elongating roots and protect the roots against infection with pathogens (Klopper and Schroth, 1981).

Results revealed that $M$. javanica don't play any role to increase root-rot disease severity when compared to the treated plants with $R$. solani alone. These results may be refer to that $R$. solani doesn't need wounds caused by nematodes to colonize the cortex, as it has the ability to penetrate and colonize these tissues without wounds.

Remarkable changes in chemical components of infected plants treated with both biocontrol agents compared with untreated plants were recorded. Results showed remarkable decrease in chlorophyll (a \& b) and carotein contents in plants infected with $M$. javanica and $R$. solani. These results are agreement with those obtained by Loveys \& Bird (1973) and Wallace (1974) who reported that, Meloidogyne infection of roots decreases the rate of photosynthesis in leaves. They reported also that high inoculum levels of
M. javanica on tomato plants caused a decline in the net photosynthesis rate within two days after inoculation. Infection with both pathogens increased the total phenol and amino acids. The increase in free amino acids may be due to the proteolysis of host proteins in response to fungal and nematode attack. The increase might be also due to the synthesis of free amino acids in fungal mycelium within the host tissues (Mousa, 1979). Results also showed enhancement in total phenol in plants and that is it may be due to the infection by both pathogens Mousa (1979).

\section{REFERENCES}

Aroian, R.; J. Griffitts; J. Wei; K. Hale; J. Whitacre; D. Huffman; K. Chien and K. McDonald (2002). Bacillus thuringensis toxin and nematodes: mechanisms of resistance and toxicity. Proceeding of the VIII International colloquium on Invertebrate Pathology and Microbial Control, Incorporating the VI International Conference on Bacillus thuringensis and the $35^{\text {th }}$ Annual Meeting of the Society for Invertebrate Pathology, 184: 225-226. Foz do lguassu, Brazil, 1823 August. Documentos Embrapa Soja.

Brian, P.W. and H.G. Hemming (1945). Gliotoxin: a fungistatic metabolic product of Trichoderma viride. Annals Appl. Biol. 32: 214-220.

Broadbent, P.; K.F. Baker; N. Franks and J. Holland (1977). Effect of Bacillus spp. on increased growth of seedling in steamed and in non-treated soil. Phytopathology 67: 1027-1034.

Cherif, M. and N. Benhamou (1990). Cytochemical aspects of chitin breackdown during the parasitic action of a Trichoderma sp. on Fusarium oxysporum 
f.sp. radicis-lycopesici. Phytopathology 80: 1406-1414.

Chet, I. (1987). Trichoderma application, mode of action and potential as a biocontrol agent of soil-borne plant pathogenic fungi. In: Innovative Approaches to Plant Disease Control. pp. 139-160. John Wiley \& Sons, New York.

Daykin, M.E. and R.S. Hussey (1985). Staining and histopathological techniques in Nematology. In: Barker, K.R.; C.C. Carter and J.N. Sasser, eds. An Advanced Treatise in Meloidogyne, Vol. II pp. 3948. Methodology, Raleigh: North Carolina State University Graphics, USA.

Hillocks, R.J. (1985). The effect of rootknot nematode on vascular pathogenicity of Fusarium oxysporium f. sp. vasinfectum in the stems of cotton plants. Annals Appl. Biol. 107 (2): 213-218.

Hussey, R.S. and K.R. Barker (1973). A comparison of methods collecting inocula of Meloidogyne spp. including a new technique. Plant Dis. Rep. 57: 10251028.

Kloepper, J.W. and M.N. Schroth (1981). Development of a powder formulation of rhizobacteria for inoculation of potato seed pieces. Phytopathology, 71: 1020-1024.

Koberiger, K.M.; D.J. Hagedorn and W.R. Stevenson (1998). Analysis of snap bean root rot potential of wisconsin fields. Wisconsin Extension Publications, No. A3242.

Loveys, R.R. and A.F. Bird (1973). The influence of nematodes on photosynthesis in tomato plants. Physiol. Plant Pathol. 3: 525-529.

Mahdy, M.E.; J. Hallmann and R.A. Sikora (2000). Biological control of different species of the root-knot nematode, Meloidogyne with the plant healthpromoting rhizobacterium, Bacillus cere- us S18. Meded. Fac. Landbouww. Rijksuniv. Gent, 65/2b.

Mahdy, M.E.; J. Hallmann and R.A. Sikora (2001). Influence of plant species on the biological control activity of the antagonistic rhizobacterium Rhizobium etli strain G12 toward the root-knot nematode, Meloidogyne incognita. Meded. Fac. Landbouww. Rijksuniv. Gent, $66 / 2 b$.

Mousa, E.M. (1979). Studies on Some Fungal Diseases Affecting Soybean in Egypt. pp 60-65. M.Sc Thesis, Fac. of Agric., Menofiya Univ., Egypt.

Mousa, E.M. and N.G.M. Hague (1988). Influence of Fusarium oxysporum f. sp. glycines on the invasion and development of Meloidogyne incognita on soybean. Revue de Nematology 11(4): 437-439.

Mousa, E.M.; F.M. Salem and G.Y. Osman (1989). Sincocin AGTM efficacy on root-knot nematode populations. Twenty-Eighth Annual Meeting of Society of Nematologists, Davis, California, U.S.A, 13-17 August, p. 549.

Mozgovaya, I.N.; B.A. Byzov; N.F. Ryabchenko and D.G. Zvyagintesv (2002). Nematicidal effects of the entomopathogenic bacteria Bacillus thuringiensis in soil. Pedobiologia 46: 558-572. Papavizas, G.C. (1985). Trichoderma and Gliocladium: Biology, Ecology and potential for biocontrol. Annual Review of Phytopathology 23:23-54.

Parvatha Reddy, P.; M.S. Rao and M. Nagesh (1996). Management of citrus nematode Tylenchulus semipenetrans by integration of Trichoderma harzianum with oil cakes. Nematologia Mediterranea 24: 265-267.

Rao, M.S.; Parvatha Reddy, P. and M. Nagesh (1997). Management of root-knot nematode, Meloidogyne incognita on 
tomato by integration of Trichoderma harzianum with neem cake. Plant Disease and Protection 104 (4): 423425.

Rosen, H. (1957). A mode field ninhydrin colourimetric analysis for acid nitrogen. Arch. Biochem. Biophysiology 67: 10-15.

Schnepf, E.; N. Crickmore; J. Van Rie; D. Lereclus; J. Baum; J. Feitelson; D.R. Zeigler and D.H. Dean (1998). Bacillus thuringiensis and its pesticidal crystal proteins. Microbiology and Molecular Biology Review 62: 775-806.

Siddiqui, Z.A. and I. Mahmood (1995). Management of Meloidogyne incognita race 3 and Macrophomina phaseolina by fungus culture filtrates and Bacillus subtilis on chickpea. Fundam. Appl. Nematol. 18(1): 71-76.

Snell, F.D. and C.T. Snell (1953). Colorimetric Methods of Analysis Including Some Tuberidometeric and Nephelometeric Methods. Vol. III, p. 606., Van Nostrand, Co. Inc., New York.

Taylor, A.L. and J.N. Sasser (1978). Biology, identification and control of root-knot nematodes (Meloidogyne spp.). International Meloidogyne Project Publication, North Carolina State University, Raleigh, p. 111.

Travers, R.S.; P.A. Martin and C.F. Reichelderfer (1987). Selective process for efficient isolation of soil Bacillus spp. Appl. Environ. Microbiol. 53: 12631266.

Vidhyasekaran, P. and M. Muthamilan (1995). Development of formulations of Pseudomonas fluorescens for control of chickpea wilt. Plant Dis. 79: 782-786.

Wallace, H. R. (1974). The influence of root-knot nematode, Meloidogyne javani$c a$ on photosynthesis and nutrient demand by roots of tomato plants. Nematologica 20:27-33.

Wei, J.Z.; K. Hale; L.K. Carta and R.V. Aroian (2001). Are Bt toxins nematicides?. Phytopathology 91: $\mathbf{S 1 4 5}$ (Supplement).

Wei, J.Z.; K. Hale; L.K. Carta; E.E. Platzer; C. Wong; S.C. Fang and R.V. Aroian (2003). Bacillus thuringiensis crystal proteins that target nematodes. Proc. Natl. Acad. Sci. 100: 2760-2765.

Weller, D.M. and R.J. Cook (1983). Increased growth of wheat by seed treatments with fluorescent pseudomonads and implications of Pythium control. Can. J. of Plant Pathol. 8: 328-334.

Wettestein, D. (1957). Chlorophyll-letal und submikroskopische formwechsel der Plastiden. Exptl. Cell Res. 12: 427433.

Zuckerman, B.M.; M.B. Dicklow and N.M. Mendoza (1995). Nematicidal Bacillus thuringiensis biopesticide. Biotechnology Advances 13: 822. 


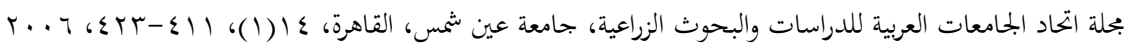

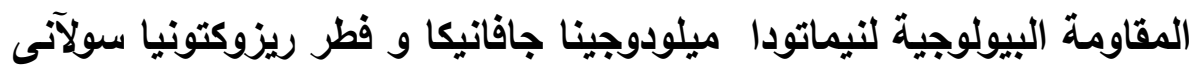 على فول الصويا بواسطة مستحضرات بكتريا باسيلس ثورينجنس و فطر ترايكودرما هارزياتم
}

$[r v]$

\author{
مجدي السيد مهلى - - رانيا زكى الثناوى '- السعيد زكى خليفة'

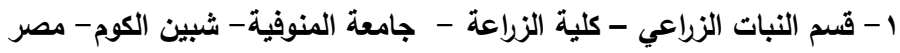

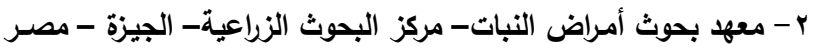

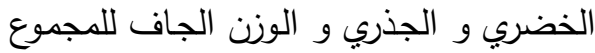

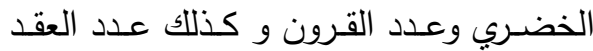

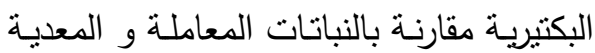

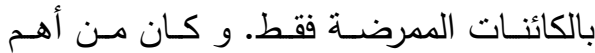
النتائج المتحصل عليها أيضا هو أن الندان النباتات

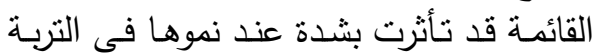

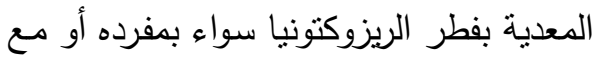

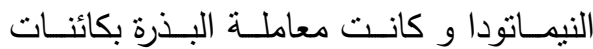

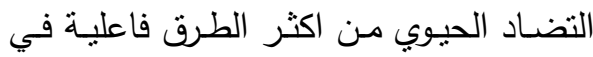

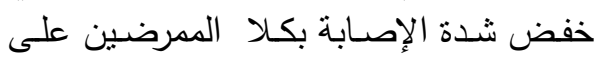
النباتات الحية القائمة.

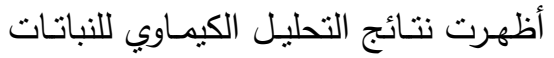

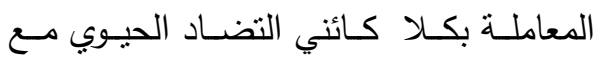

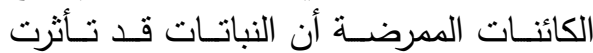

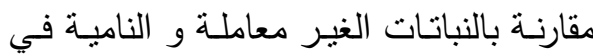

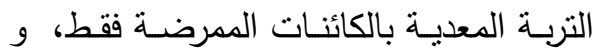

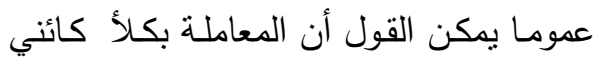

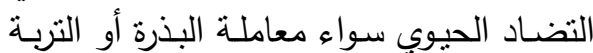

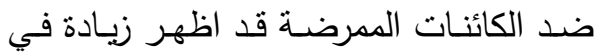

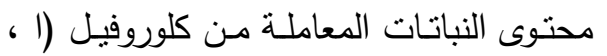

تم استخدام مستحضرات لكل من البكتريا

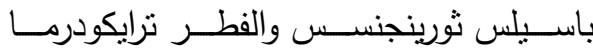
هارزيانم سواء كمعاملة البذور أو التربة وذلكئل

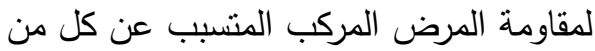

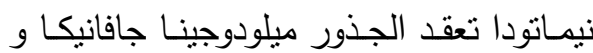

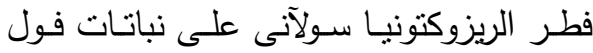

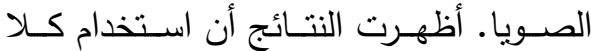

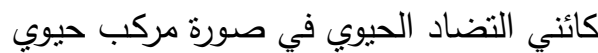

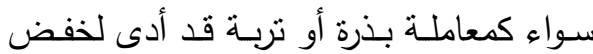

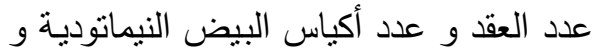

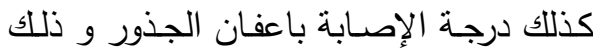

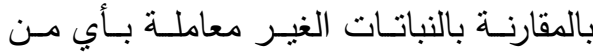

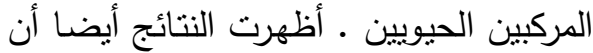

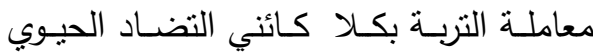

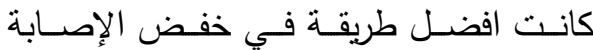

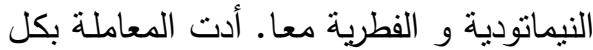

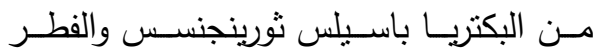

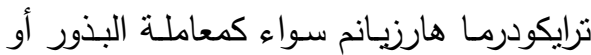

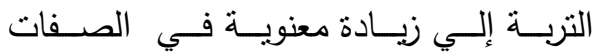
الخضرية للنباتات مثل الوزن الطازج للمجموع التري 
ب) و الكـار وتــين والفينـولآت والأحمـاض الغير معاملة و النامية في تربة معدية بالفطر

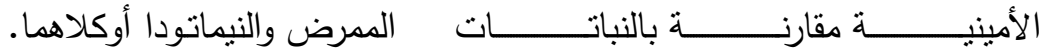

\footnotetext{
تحكيم: ا.د أحمد أحمد موسىى ا. ا.د محمد الأمين سويلم
} 